\title{
Introduction: Departures, Emanations, Intersections
}

\author{
Thomas O. Beebee
}

The point of departure [Ansatzpunkt for world literature] must be the election of a firmly circumscribed, easily seen, set of phenomena whose interpretation is a radiation out from them and which orders and interprets a greater region than they themselves occupy.

Erich Auerbach, "Philology and Weltiteratur" $135^{1} \quad 13-14$

World literature is an elliptical refraction of national literatures.

David Damrosch, What is World Literature? 281

Following the sentence I have chosen for the first epigraph, Erich Auerbach, a figure of immense importance in the fields of both comparative and world literature, goes on to propose the methodology of stylistics as one such circumscription of a set of phenomena. What if we, instead, were to take a national literature as such a set, as David Damrosch seems to be proposing in his geometrical metaphor? Indeed, it is difficult to imagine how a philology of Weltliteratur (which is the title of Auerbach's piece in German) could be managed without paying detailed attention to one or more individual language traditions. The difference that Weltliteratur makes to philology, in the words of Aamir R. Mufti, is that "the perspectivism of the Ansatzpunkt becomes the means to a new kind of synthesis, a self-consciously partial and 'discontinuous history' that seeks to establish contingently its own archive across borders and boundaries - of language, nation, continent, civilization, and tradition."2 This volume of essays aims at providing one such partial and discontinuous literary history as one of several possible entry points to world literature. In other words, this collection of essays on German literature takes Auerbach's suggestion as its basis, reading his admonition as an alternative way of "performing" world literature. Rather than "do" world literature either as a corpus of texts or canon, as occurs e.g. in the compilation

1 Works that appear in the Bibliography, as both Auerbach and Damrosch do, are cited in abbreviated form, and frequently in text as here; works that don't appear in the Bibliography are cited in modified Chicago style.

2 Aamir R. Mufti, "Erich Auerbach and the Death and Life of World Literature," in D'haen and Kadir, eds, The Routledge Companion to World Literature, 78. 
of anthologies such as those published by Norton, Bedford, or Longman, or else as a series of isolated, exemplary comparative readings (as performed for example by David Damrosch in his What is World Literature?), we attempt here the re-visioning of a specific "national" linguistic canon as a particular nodal point of world literature's international, intersystemic relations. At the same time, however, we may speculate as to whether we might reverse subject and predicate in Damrosch's formulation-our second epigraph above-and still have a legitimate constative statement: "National literatures are elliptical refractions of world literature." The ellipses referred to herechosen by Damrosch for his metaphor due to their double foci, namely the culture of origin vs. the culture of reception of a literary work or corpus-closely resemble the Venn-diagram Schnittmengen (intersections) that are created when the circles of national literatures overlap with each other-for example when translation activity forms part of a national canon (see Figure 2 below). These are the "contact zones" of world literature. One sub-set of these intersections are what Jürgen Joachimsthaler has called Text-Ränder (text-margins), a concept that I explain below.

As a first step in providing content for the ellipsis idea, and perhaps for moving beyond it to a multidimensional modeling of the interaction of literary systems, we present this collection of essays on German literature in its international dimensions. While not the first such effort in international Germanistik, the fact that there is not a single index entry for world literature (nor for Weltliteratur) in the otherwise very comprehensive "companion" to German Studies in the United States edited by Peter Uwe Hohendahl indicates a need for a volume of essays dedicated to the topic. ${ }^{3}$ While no single volume can deal comprehensively with such a vast topic as the elliptical refraction of German literature in world literature (and vice versa), the present essays have been chosen so as to cover a historical range within the modern period, with a variety of approaches and authors represented. Together, the chapters address the systematic nature of the relations between German national literature and world literature as these have developed through institutions, cultural networks, and the careers of individual authors.

The present collection thus joins analogous efforts focused on other traditions, for example Adam Barrows's The Cosmic Time of Empire : Modern Britain and World Literature (2012), and Shades of the Planet, edited by Wai Chee Dimock and Lawrence Buell, which solicit their respective national literatures, British and American, to reveal their world dimensions. The question with which the editors of the latter collection begin their introduction seems relevant to our own inquiry as well:

What is "AMERICAN LITERATURE"? Is it a sovereign domain, self-sustained and self-governing, integral as a body of evidence? Or is it less autonomous than that, not altogether freestanding, but more like a municipality: a secondtier phenomenon, resting on a platform preceding it and encompassing it,

Peter Uwe Hohendahl, ed., German Studies in the United States: A Historical Handbook (New York: MLA, 2003). 
and dependent on the latter for its infrastructure, its support network, its very existence as a subsidiary unit? ${ }^{4}$

The name of any other national literature can be substituted for "American" here without altering the fundamental question being asked. The language of sovereignty and municipality suggest themselves in the case of "American" (by which the editors mean US) more than in that of German literature, since US literature can designate a variety of linguistic artifacts related to a single political unit, whereas German literature in this volume means verbal art in a single language (allowing for dialectal variants) produced by subjects or citizens of at least five different nation-states (Austria, Germany, Switzerland, Liechtenstein, and Luxembourg), and beyond that by a constellation of emigrés and adoptees. Transferable, however, are questions of the degree of systemic autonomy and autopoiesis in national traditions. Given that this question of degree does not admit of a univocal or unambiguous answer, our purpose in this volume is to highlight the porousness of the boundaries of German literature and to adumbrate that larger platform of world literature that it rests on.

From this point forward, both "world literature" and "Weltliteratur" will be referenced together under the acronym WL (except in titles, sub-headings, and quotations, where the full phrase will be preserved). Are not the German and the English WL equivalent, one might ask? In many senses, yes, the semantic overlap or Schnittmenge between the two terms is extensive. For example, both differentiate themselves against alternative formulations with "national": "national literature" and "National-Literatur," respectively. And since neither term possesses a clear or univocal meaning, attempts at definition of the two terms may coincide or cross each other. But as with most cognates, the fun begins with the subtle distinctions. As Martina Kolb points out in her essay on Brecht, the German version suggests a synonymous phrase where the two nouns, "Welt" and "Literatur," are linked by a preposition-but by which one? "Literatur der Welt," "Literatur in der Welt," or "Literatur von der Welt" are all possibilities, as are conversions of the noun into an adjective: "weltbekannte Literatur," "weltweite Literatur," or even "weltliche Literatur." But instead of any of these more precise limitations of the concept of WL, we are left with the enigmatic composite. In German, as in French, "world" can mean not the globe, but simply society, a valence that has been mostly lost in English usage. The German thus points towards a cosmopolitan element of WL that is certainly discernible in Johann Wolfgang von Goethe's pronouncements. Oswald Spengler took up this aspect of WL in his highly influential cultural critique and attempt at world history, Der Untergang des Abendlandes (1918-22; The Decline of the West). Spengler makes the following reference to WL: "[WL] ist die führende weltstädtische Literatur" (WL is the dominant metropolitan literature). ${ }^{5}$ In English Spengler's point is almost lost, because it lies in the progression from Stadt (city) to Weltstadt (metropolis). The opposite of world literature, in Spengler's view, is not national literature, but provincial literature that is bodenständig

4 Wai Chee Dimock and Lawrence Buell, eds, Shades of the Planet: American Literature as World Literature (Princeton: Princeton University Press, 2007), 1.

5 Spengler, Der Untergang des Abendlandes (Munich: Beck, 1963), 684. [My emphasis. My translation.] 
(telluric). The remark occurs in a segment of the book where Spengler is explaining the triumph of city life in the development of civilization. In the process, Spengler draws a binary distinction between culture-specific and "universal" artistic forms. His conclusion, that there is commonly more distinctiveness between the metropolis of a region and its telluric hinterland than between the various metropolises themselves, resonates with a number of contemporary critiques of globalization, and of WL as a technology of recognition that homogenizes all: wherever one goes today, one finds Berlin, London, and New York, just as the Romans encountered the familiar monuments of "their" culture in Palmyra, Trier, and Timgad. WL, for Spengler, is the literature appropriate to those metropolitan publics which are, whether they are aware of it or not, also cosmopolitan publics. Interestingly, here Spengler seems to go back before Goethe to C. M. Wieland's marginal notation, "Weltlitteratur," in the latter's translation of the Roman poet Horace. Wieland seemed to be indicating just this: that the inhabitants of the capital of Rome were educated in a literature that was not distinctly Roman, but cosmopolitan.

A WL perspective sees how national literatures define themselves over, against, and through their others. German literature has constructed itself with a view to those others, from French Classicism to Shakespeare to the Chinese novel that Johann Wolfgang von Goethe discussed with Johann Peter Eckermann on the last day of January in 1827, thereby creating a locus classicus for the discussion and definition of WL. At the same time, German literature has been translated, read, and absorbed in a majority of languages of the world, from Napoleon's devouring of Goethe's 1774 Leiden des Jungen Werthers (Sorrows of Young Werther) to the Nobel Prize for Literary Achievement awarded to Herta Müller in 2009. To give two examples from outside Europe, in 1923, Mohammad Iqbal, a renowned poet in both Urdu and Persian and one of the founders of Pakistan, published his Payam-i-Mashriq (Message from the East), which he conceived as a response to Goethe's West-östlicher Divan (1819, revised edition 1827; Western-Eastern Divan). Goethe had written his last poetry collection under the influence of the Persian poet Hafiz, whose work Goethe had read in Joseph von Hammer's 1814 German translation, and whose poetic persona he adopted for the Divan. ${ }^{6}$ In a harrowing, autobiographical fiction called "A Fool's Life" (1927), the Japanese author Ryūnosuke Akutagawa wrote the following:

The [West-östlicher] Divan was going to give him [Akutagawa] new life. Till now he had been unaware of the "Oriental Goethe." With an envy almost approaching despair he saw Goethe standing on the far shore beyond good and evil, immense. In his eyes the poet Goethe was larger than the poet Christ. The poet's soul holds not only the Acropolis or Golgotha. In it the Arabian rose also blooms. If only he had strength enough to grope in the poet's footsteps. ${ }^{7}$

6 On the Iqbal-Goethe asynchronous exchange, see Anil Bhatti, "Iqbal and Goethe," Yearbook of the Goethe Society of India (1999-2000), 184-201; and Anil Bhatti, "Der Orient als Experimentierfeld. Goethes Divan und der Aneignungsprozess kolonialen Wissens": 23-4.

7 Ryūnosuke Akutagawa, "A Fool's Life," in Ryunosuke Akutagawa: Hell Screen, Cogwheels, A Fool's Life, trans. Will Petersen Grossman (Hygiene, CO: Eridonos, 1987), 129. 
In Akutagawa's view, the creative pseudotranslation represented in the Divan had enabled Goethe to enter the realm of reconciled literary existence that the Japanese author, who wrote a number of works as responses to European authors such as Pierre Loti and Anatole France, longed for but could not attain. His citation of the Divan thus invokes a polylingual, multicultural force-field that is the system of WL in miniature.

It is such processes of translation, dialogue, and rewriting that create the worldwide web of literary textuality. From the Germania of Tacitus to the Chinese studies of Leibniz, from the eastward gaze to India of Friedrich Schlegel and Hermann Hesse to the emergence of Turkish-German literature and the presence of Russian-German writers such as Wladimir Kaminer on the current scene, German literature has been imbricated in other cultural traditions. It has ventriloquized other cultures, taken them as mimetic objects, translated and transadapted their texts. Other cultures of the world have, as in the examples above, done the same with German literature. German literature has been written in non-German-speaking countries, and by people for whom German is a second language. German authors have been of vital importance to people who encounter them for the first time in English, Japanese, Spanish, Urdu, and other translations.

This collection of essays on these and other transnational moments will together produce an image of, and further the conversation about, German literature as WL. If the foregoing sounds at best cosmopolitan and at worst triumphalist, our purpose is not to show German literature's universalist appeal, nor to proclaim its important role in the creation of WL. Rather, we hope first of all to shift the terms in the discussion of German literature as a national literature through consideration of the WL component, and secondly, to begin the analysis of its place within a system of WL that includes tensions, rivalries, silences, and untranslatabilities. In what follows of this brief introduction to our topic, I will first say more about the slippery concept of WL, before addressing the creative tension between presenting German literature as $\mathrm{WL}$ and as German literature.

\section{What does it mean to study world literature?}

As with most important topics in the humanities, there is more than one way of understanding the concept of WL. It is useful to have a palette of potential definitions. Five of the more common ideas of WL are:

1. the comprehensive total of all the world's literatures

2. a hypercanon of the best that has been thought and said worldwide

3. literature as an anthropological constant in human cultures

4. the processes of diffusion and consecration by which locally produced authors, texts, and literatures become globalized

5. literature written with a global or transnational readership in mind.

Concept \#1 stricto sensu must remain an ideal form, beyond the cognitive capacity of any single human to realize in its actual phenomenal variety. The urge for 
however

comprehensiveness does play a role, therefore, on the level of national and linguistic inclusiveness in the writing of world literary history, as well as in the compilation of anthologies or lexicons of WL. There have been attempts at conceptualizing the wholeness of WL on a more abstract level, and at writing histories of WL. G. F. W. Hegel and his followers did attempt to adumbrate a world-system of art, starting from the notion of the obedience of all forms of art to the workings of the Absolute. Moriz Carrière's Die Kunst im Zusammenhang der Culturentwickelung und die Ideale der Menschheit (Art in its Relation to the Cultural Development and Ideals of Humanity), composed in five volumes between 1863 and 1888, was an attempt at just such a universal history of art and literature, beginning in Asia and moving to Europe-though not considering Africa or the Americas. Unlike Carrière, compilers of most contemporary US anthologies concern themselves with the inclusion of as many different traditions as possible. For example, the Norton Anthology of World Literature was infamous for not being true to its title until a so-called "expanded edition" was published in 1995. Until then, the Norton Anthology of World Literature had been in fact an anthology of Western masterpieces. The Longman Anthology of World Literature includes, to be sure, literary artifacts composed originally in Native American and African languages, but beyond that in Tibetan, Turkish, Urdu, Vietnamese, and other languages.

Approach $\# 2$ is meant to help solve the problem of unsurveyability by including only the finest works from many traditions, or, perhaps more crucially, those works that appear finest within the language system(s) into which they are translated to become WL. A concrete, three-dimensional example of this approach to WL has been given us by Martin Bodmer, who founded a Library of World Literature in Cologny (Geneva), Switzerland. Bodmer began in 1951 with 70,000 books and manuscripts; today the library counts over 160,000 unique items. In his introduction to the library, Bodmer notes that "Dichtung" (translating roughly "verbal art") forms the imperishable core of WL. He then asks how one can tell "authentic verbal art" (echte Dichtung) among the dross of publication. Time is the great alchemical process from which emerges the gold of true verbal art: "Concerning authenticity there can be no deception. Time smelts it out [herausschmelzen] so purely and surely, as people smelt gold from ore" (Bodmer, Bibliothek der Weltliteratur 9). Naturally, Bodmer's prosopopoetized "Time" needs to be populated with agents and institutions. Time does seem, in and of itself, to eliminate history and politics from literary works, and even from forms and genresat some point, epic, which means "song," lost its function of inspiring warriors to battle and took on a different, more prosified purpose, a change already discernable in literary epics such as the Nibelungenlied (Song of the Nibelungs). Thomas Beebee's chapter on the Nobel Prize for Literary Achievement shows how the most famous single institution of WL fought against time in attempting to canonize the work of Paul Heyse that was too fully imbricated in his epoch to survive into the twentieth century.

We owe to David Damrosch the coining of the term "hypercanon" to describe the select constellation of texts that make up WL. ${ }^{8}$ The poet Durs Grünbein, on the other

8 David Damrosch, "World Literature in a Postcanonical, Hypercanonical Age," in Saussy, ed. Comparative Literature in an Age of Globalization, 43-53. 
hand, has supplied the most appropriate metaphor for this view of WL as consisting only of peaks: "Es gibt einen Himalya der Literatur, und seine Höhenzüge sind bestens bekannt. Dieses Weltgebirge wird unstreitig von einer Kammlinie aus Sieben- und Achttausendern dominiert, die dort schon seit Jahrhunderten aufragen" [Literature has its Himalaya range, and its peaks are quite well known. This world-range is unequivocally dominated by a backbone of 7000- and 8000-meter peaks that have towered above the rest for centuries] ("Weltliteratur - ein Panoramagemälde," 23). Grünbein extends the metaphor into allegory as he lovingly describes snow-covered Dante Peak, crenellated Mount Shakespeare, and others, with Goethe among them in a milder light and showing some green meadows. While mountains may be perspectival, Grünbein argues metaphorically, everyone can agree that they have a place in the landscape: "Mag sein, dass die Reiserouten dorthin umstritten sind, die Landkarten widersprechende Angaben machen, einig ist man sich in der Himmelsrichtung. Das Gebirge der Weltliteratur liegt, nicht nur von Tibet aus gesehn, im Westen" [If the travel routes to get there are in dispute, if the maps give conflicting information, we at least agree on the orientation. The mountain range of world literature lies-and not only when seen from Tibet-in the West] (ibid., 24). Grünbein ends with a discussion of the paradox of contemporary WL, which in reality includes only works that have been straightjacketed into planetary conformity by the market pressures of world bestseller-literature, leaving us to imagine the "Inseln der seligen Unbekannten mit ihren seltenen Vogelarten, verloren für die nach fremdartiger Empfindsamkeit hungernde Intelligenz" [islands of the blessed Unknowns, with their rare species of birds, lost to an intelligentsia eager for foreign sentiments] (ibid., 32).

The hypercanon of WL frequently involves conflicting mappings of the literary landscape; first and foremost, the hypercanon does not inevitably consist of the texts or authors considered most worthy from the perspective of national canons-which latter are themselves hardly stable objects, but more clusters of probabilities. The essays by Daniel Purdy and Chunjie Zhang confirm the truth of this statement: the famous novel that Goethe refers to in his seminal conversation in 1827 with Eckermann on the topic of WL is not one of the great classics, such as the Hong lou meng (Dream of Red Chamber), which had not yet been translated. No, it is a secondor even third-rate specimen, Abel Rémusat's French translation of the Iu-Kiao-Li as Les Deux Cousines, hich beceme a European bestseller upon its publication in 1826. That Chinese novel in French became the immediate provocation for the discourse on WL. But decades earlier, another Chinese novel, the Hao Qiu Zhuan, translated from English into German in 1766 by Christoph Gottlieb von Murr under the title Haoh Kjöh Tschwen, d.i. die angenehme Geschichte des Haoh Kjöh, had also come to Goethe's attention.

If WL sometimes operates as a shadow-canon rather than a hypercanon, as mentioned above, there can also be interesting discrepancies between linguistic and political belongings. Franz Kafka's prominence in WL obscures his position in the Czech or Austrian canon. In the case of the Austrian poet Rainer Maria Rilke, who is the subject of Kathleen Komar's chapter in this volume, however, translatability and national canonization go hand in hand. Komar compares Rilke's popularity in 
WL, shown in everything from intertextual references to repeated translations of his work, with the shadow status of the American poet Wallace Stevens. Certainly a "must-read" for anyone interested in anglophone poetry, Stevens has been translated much less often into other languages and remains a diminished presence in WL. (The anglophone poet most equivalent to Rilke Stevens, with many translations, would probably be T. S. Eliot.) There is a similar conjunction in the case of Bertolt Brecht, though as Martina Kolb proceeds to demonstrate in her piece, Brecht's entry into WL has more material aspects, given his years of exile and forced wandering from country to country. Brecht himself became a literature-vector that spread his unique form of modernist theater-itself synthesized out of heterogeneous influences, from Russian formalism to Asian performance practices-to other parts of Europe and the Americas, resulting in an incalculable shift in the terms of playwrighting and filmmaking worldwide. Contrasting with these synchronizations of national and WL canonicity are the fates of Rudolf Eucken and Paul Heyse. As I show in my own piece on these forgotten Nobel Prize winners, the impact of the award in Germany was relatively muted compared to its international resonance, and it failed to halt the gradual disappearance of these authors from their respective canons.

A limitation of the usefulness of the hypercanon idea is that it seems based on a questionable temporal and territorial sequence, in which national literature canons are created first, through their own internal processes, to then be culled by the mechanisms and processes of WL so as to form hypercanons. It can be demonstrated, however-indeed, the present volume is intended as one such demonstration-that there are international, cross-cultural factors at work in the creation of national canons. If nothing else, as Pascale Casanova points out, national literatures-which do not, despite the asseverations of J. G. Herder and others, emerge from the Volk (people) or bear a definable relationship to "national character"-can only define themselves vis à vis each other, resulting in a mutual conditioning of national literatures within a web of relationships.

Beyond translatability, Mads Rosenthal Thomsen has formulated the idea of WL as a system, in which there is positive feedback (i.e., a "snowball" effect), inasmuch as constellations of works draw other texts with similar features into their orbit:

The international canons consist of several constellations of works that share properties of formal and thematic character, where canonized works can bring attention to less canonized, but affiliated, works, and draw them into the scene of WL. By studying such constallations, a challenging and realistic mapping of WL is possible. There has been [...] too little critical thought based on the mapping of social selection combined with a textual approach that seeks constellations across time and space. (Mapping World Literature 3)

David Kim's essay in this volume on the writer W. G. Sebald seeks to define one such constellation, that of a militant melancholy forged by global events such as the Holocaust. In terms of genre, the novel (as in Sebald's work) is perhaps the most highly visible of these constellations, and has been the tip of the spear for placing postcolonial literatures on the stage of WL. Works far from these constellations, on the other 
hand, experience the untranslatability that Emily Apter has identified as constitutive of WL in her book Against World Literature. Apter proposes a focus on untranslatabilities as "a deflationary gesture toward the expansionism and gargantuan scale of world-literary endeavors" (3). Untranslatables are one element of what lies outside the Schnittmengen between cultures.

In contrast, concept \#3, that of anthropological constants, implying the translatability of forms, genres, images, and themes, is a useful approach for some of these, while \#4, the idea of fusion, forms its complement for others. The idea of myth and folktales as forms of storytelling that arise in cultures independent of each other motivated works such as Sir James George Frazer's Golden Bough compilation, while comparison of the lyric traditions of Europe and Asia has been a favorite topic of comparative scholarship, for example in James Liu's Language, Paradox, Poetics: A Chinese Perspective and Earl Miner's Comparative Poetics. ${ }^{9}$ These, and other comparisons of European with Chinese lyric, rest on the assumption that the same literary form exists on both continents, and that there is a translatability between the terms "lyric" and shi. In contrast, other forms such as the novel appear as examplars of the same processes of diffusion that create WL. Franco Moretti's multivolume, polymathic approach to the question in the complex, multi-authored reference work The Novel is of interest here. While it is an edited set of volumes, The Novel's organizational structure already makes an important point-or rather, two complementary points: "Toward World Literature" follows on "The Circle Widens" that follows on "The European Acceleration" that follows on "Polygenesis." ${ }^{10}$ The implicit argument here is that while in one sense the novel is, like myth and lyric, a literary form that arises independently in several cultures, in another sense it is a European form that expands and is carried and imitated around the globe, creating what today is a world genre in which Günter Grass, Haruki Murakami and Paulo Coelho compete with each other for readership thanks to the work of translation. One of David Damrosch's several definitions of WL, that it is composed of works that on balance gain rather than lose in translation, invokes this process of diffusion in a striking way (What is World Literature? 233).

The contemporary novel brings us to category \#5, WL as literature intended for a global audience. This applies to a certain type of author, and has a temporal vector, since increased rapidity of transportation and communication shrinks the globe and causes an ever-greater variety of cross-cultural entanglements. An example is W. G. Sebald, who wrote his novels about emigration and dislocation in German while holding a professorship at the University of East Anglia in Great Britain, while another is the bilingual (German-Japanese) writing of Yoko Tawada, or the 2008 novel Änderungsschneiderei Los Milagros by the Argentine writer Cecilia Barbetta, which takes place entirely in Argentina, to mention only a few examples. In her piece that closes out our volume, Elke Sturm-Trigonakis has called category \#5 the "neue

9 Sir James George Frazer, The Golden Bough, 3rd edn, 12 vols. (London: Macmillan, 1906-15); James Liu, Language, Paradox, Poetics: A Chinese Perspective (Princeton: Princeton UP, 1988); Earl Miner, Comparative Poetics (Princeton: Princeton UP, 1990)

${ }_{10}$ Franco Moretti, ed., The Novel, 2 vols. (Princeton: Princeton UP, 2006), 1: v-vii. 
Weltliteratur," which she defines as "a concept which allows the establishment of a new literary system on the same rank with already defined literary systems such as national literature, postcolonial literature, or others" (177). The texts of new WL feature more than one language, at least implicitly, and they portray conditions of globalization, or the "oscillation between transnationalism and regionalism in terms of character, setting, and time." ${ }^{11}$

In contrast to what Goethe appeared to think would happen, and also to the growth of the literary marketplace in general, interest in WL has not experienced a steady upward trend over the past two centuries. Or perhaps more accurately, one may speak of the "uneven development" of WL in horizontal terms. For example, the post-1945 Cold War saw a predominance of comparative literature and Western Masterpieces rather than WL, as literature became an important carrier for Western values in the face of a perceived threat from totalitarian, Communist states. Conversely, however, a search for WL terms during this period turns up countless publications from behind the Iron Curtain. The impulse towards WL in the DDR (East Germany) went hand in hand with the self-proclaimed internationalism of Communism, and of the official version of the Soviet Union as an anthology of different ethnicities. I. G. Neupokoeva's contribution in a 1968 volume on comparative method published in East Berlin strikes the typical tone of solidarity, urging the study of WL as a way of isolating and valorizing revolutionary literature produced within capitalist frameworks: "By means of comparative analysis of the history of WL, a specific sampling of the revolutionary literature of the capitalist world just after the Great Socialist October Revolution [Grossen Sozialistischen Oktoberrevolution] can become part of a general exposition of literary developments in that period. Interesting patterns [Gesetzmässigkeiten] are thereby revealed" ("Probleme der vegleichenden Literaturbetrachtung in der 'geschichte der Weltliteratur'” 65). Helmut Baldauf edited a collection, Schriftsteller über Weltliteratur (Writers on WL), based on a series of radio programs, "Literatur aus aller Welt" (Literature from Everywhere), that consisted of East German authors (Günter Kunert, Franz Fühmann, etc.), describing their encounters with the texts of WL. Oddly, the anthology also includes as part of WL texts originally written in German, such as for example Stephan Hermlin's piece on Georg Trakl (Baldauf 63-7). In his brief epilogue, Baldauf avoids the stridently political, and emphasizes ${ }^{\text {ing }}$ instead the insights achieved through the technique of collecting personal relationships between practicing authors and the body of WL. These are just a select two out of nearly innumerable examples of the valorization of WL approaches in Communist East Germany during the period of that country's existence. Only a few of these have been retained in the Bibliography for this volume.

Conversely, it would be difficult to overlook the breaking down of the Wall and of the Iron Curtain in general, and the resulting processes of globalization as significant factors driving the revival of interest in WL in the West starting in the last decade of the twentieth century (though also beyond, as in the recently formed, globetrotting Institute for World Literature that has met not only in Cambridge, Massachusetts, but

11 Elke Sturm-Trigonakis, “Die Neue Weltliteratur," IDE 1 (2010), 29. 
also in Beijing and Istanbul). One reason for the explosion of WL theory, pedagogy, and methodology (partly documented in the Bibliography to this volume), as opposed to actual "world lit crit," is the difficulty of accomplishing either WL criticism, or world literary history. The capaciousness, as well as the polylingual and multicultural features of WL present formidable obstacles to its study, and call for collaborative approaches that conjoin a range of expertise. It is, to use Auerbach's phrase, crucial to find the correct Ansatzpunkt or point of departure. The present collection of essays on German literature as WL contributes to the critical study of WL in its textual, institutional, and translational realities, while at the same time highlighting a question that has hitherto received insufficient scholarly attention: what is the relation between national and world literatures, or, more specifically, in what senses do national literatures systematically participate in (or resist) WL?

While it is common to refer the origins of the concepts of both Weltiteratur and comparative literature to the German-speaking world, and especially to the scattered remarks of Johann Wolfgang von Goethe, far less attention has been paid either to reading German literature as WL, or to documenting how Goethe's injunction was carried out-or not-in Germany itself. Of course, comparative methodology has long been applied to German literature, with often revealing and sometimes surprising results. Comparative methodology is vital to making sense of WL. At the same time, however, consideration of German literature as part of an international network of literary discourse, complementing the autonomous aspects of its specific national, linguistic, and cultural polysystems, must inevitably alter the application of comparative method. In particular, the perspective of WL must expand comparatism beyond the confines of literary credit-and-debit accounting (e.g., as elaborated in so-called "influence studies"), to a more comprehensive and objective attempt at coming to grips with how meanings and traditions travel. ${ }^{12}$ Whereas the vast majority of comparative and transnational work on German literature has been confined to its derivations from the Classical heritage, with Germany and Austria's surrounding geographical neighbors (more on this below), or with the multiculturalism of Switzerland, many of the essays in this volume consider more geographically removed cultures, e.g. China (in the chapters by Daniel Purdy and Chunjie Zhang) or Spanish America (in the piece by Paul Nissler), and also "minor" other cultures such as the Slavic hinterland of the Austrian empire (in the essay on Hugo von Hofmannsthal by Simona Moti) or the cultures of origin for immigrants to German-speaking countries, as enumerated by Sturm-Trigonakis.

Whereas the comparative approach has historically been one of tracing inputs and outputs (seen frequently, unfortunately, as thematic, stylistic, or ideational credits and

12 This language of "cultural bookkeeping" comes from René Wellek, wh@ritiłted59 published an important programmatic essay, "The Crisis of Comparative Literature," in Damrosch, ed., The Princeton Sourcebook in Comparative Literature, 161-71. See especially p. 167. Wellek called for overcoming such bookkeeping in favor of the shared values of literary imagination and human creativity. I do not mean to imply that comparatists work only or even primarily with a binary model, but Wellek's characterization may indicate that the engagement with WL is one factor that has caused comparatists to abandon cultural bookkeeping. 
debits), a WL approach is more one of constructing a supralinguistic constellation of relationships between texts, languages, and cultures. Hence, a diagram such as Figure 1 below indicates a relative balance of inputs and outputs between German literary production and that of another language. I have chosen Chinese among dozens of possible languages in homage to its honored place in the single most-cited and anthologized discussion of WL by Goethe, which begins with Goethe's remark to Eckermann that he has been reading a Chinese novel, to which the former reacts with surprise and some skepticism that such an exotic cultural product can exist.

In the actual practice of criticism, one or the other of the terms of this one-dimensional interchange will be exemplified by a single author, so that we understand what Friedrich Schlegel and Hermann Hesse absorbed from Asian literatures, for example, or Goethe's reception in China. ${ }^{13}$ Let me contrast the binary exchange model with the Schnittmengen of Figure 2: the diagram is limited by considerations of space to just five sets, and also to a deceptive two-dimensionality, when in fact literature possesses either multiple or zero dimensions. With a bit of imagination, perhaps the reader can see these rings as slices of spheres stacked next to each other, but in such a way that they intersect. The influential Germanist Julius Petersen, who was also long-time editor of the best-known German comparative journal, Euphorion (which he renamed Dichtung und Volkstum, see the discussion below), spoke of these intersections in an address to the Goethe-Gesellschaft, calling them not Schnittmengen but "Zwischenzonen" in a 1927 address with the dramatic title "National or Comparative Literary History?":

National literatures overlap in two areas, therefore: that of the use of foreign languages; and that of the linguistic appropriation of foreign creations, such that internationalized intersections [Zwischenzonen] arise, which represent a common possession: the Waltharius [a Latin composition ca. 1000 C. E. based on Germanic tradition] belongs to the tradition of the Latin Middle Ages no less than it does to German literary history. (Petersen, "Nationale oder vergleichende Literaturgeschichte?" 45)

A more literal translation of Zwischenzonen would be "between-zones," but I have used "intersections" here in order to refer back to the concept of Schnittmengen that I find analogous to what Petersen presents here. Petersen's concept of the systems model of Figure 2 was atomistic: the genius and quality of individual authors enter the space of WL and create effects, which he describes as happening when "the emanations [Ausstrahlung] of a genius in all directions through space and time-their transformation through the centuries and various peoples-are brought together in a summary overview, just as von Bernays planned to do with his Homer in

13 On Schlegel, see for example Michael Dusche, "Friedrich Schlegel's Writings on India," in Deploying Orientalism, ed. James Hodkinson and John Walker (Rochester, NY: Camden House, 2013), 31-54; on Hesse, see for example the Symposium on Hesse's Siddhartha at http://www.asian-studies.org/ eaa/siddhartha.htm. Accessed 24 March 2014. On the latter, see for example Günther Debon and Adrian Hsia, Goethe und China- China and Goethe (Bern: Lang, 1985). Further references can found in the essays by Purdy and Zhang, and in Todd Kontje, German Orientalisms. 


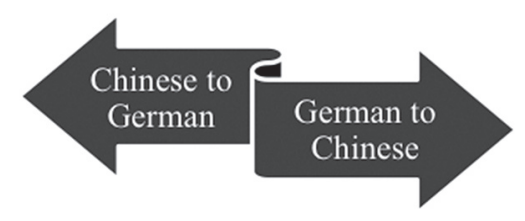

Figure 1 Comparative Model

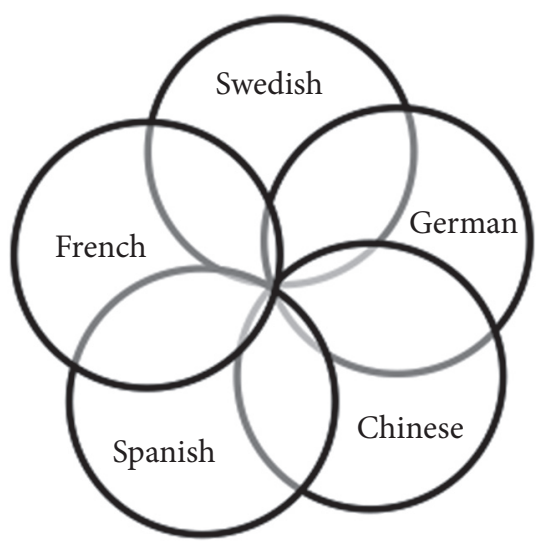

Figure 2 World-Literature Model

World Literature, or as other considerations on the world influence of Virgil, Dante, Shakespeare, or Goethe might bring forth." ${ }^{14}$ "Ausstrahlung" is an interesting wordchoice, given that "Ausstrahlungskraft" is the Germanic equivalent of "charisma." In this model, the idea of a national literature is no longer central. The solid location of "Gebiet" (field) is replaced by an "allseitige Ausstrahlung" (emanations in all directions). A single author or work appears in multiple languages and guises. In our own volume, Kathleen Komar has provided an excellent example of this approach using the poet Rainer Maria Rilke, who joins Tu Fu, Rumi, and Walt Whitman as a premiere poet of WL, with his work translated into virtually all of the world's literary languages. In either case, Petersen invokes Auerbach's injunction avant la lettre, highlighting scholarship that proceeds from a single, well-defined Ansatzpunkt. ${ }^{15}$

But far more data is needed in order to construct the second model, the worldsystem of literature, and to outline German literature's place within it. We should imagine the rings of the second diagram as the outlines of spheres, stacked together like the three-dimensional model of a molecule. Furthermore, those parts of the diagram that do not intersect with any other literature should carry a symbol to indicate something analogous to electrical repulsion of one literature by another,

14 Ibid., 47. Petersen refers to Michael Bernays (1834-97), one of the last polyhistorians, who wrote on Goethe's Homer reception.

15 Remarkably, the following year (1928) saw a similar intervention, this time by the distinguished Romanist Karl Vossler. See his "Nationalliteratur und Weltliteratur." 
non-contact or untranslatability, which may occur due to material reasons, politicoreligious pressures, or the relative impermeability of the autonomous aspects of a literary system to outside influences. And the circles, of course, are two round and closed, creating the impression that "national" literatures are excessively definable and homogeneous, when in fact they are generally riddled with what Hamid Tafazoli and Richard Gray have termed (coining off of Michel Foucault) "heterotopias," ranging from dialectal and bilingual writing within national spaces to authors' hyphenated identities (Tafazoli and Gray, Heterotopien in Kultur und Gesellschaft). I have also drawn them to be excessively equal to each other, when in fact, "Weltliteratur is [...] one and unequal," in Franco Moretti's words. ${ }^{16}$ A variety of forces impinge on literature at any time that it encounters a public, but especially when it enters the world stage (or attempts to). Manfred Koch formulates it thus: "Literary exchange between nations is never brought about merely according to the sublime criteria of artistic quality and cultural sympathies. Wherever there is a market, competition rules. Even in the market for world literature a contest of elimination [Verdrängungswettbewerb], in which it is not necessarily the wealth of intellect that triumphs, but the power of the respective culture industry [Kulturindustrie]."'17

Few developed literary markets throw up greater barriers to translation than does the US, for example, while German has much greater tolerance for translated literaturethere is no US equivalent to the Frankfurt Book Fair, for example. The specific choices made by different literary systems (and, yes, non-human systems do "decide" things) that result in their not interacting with each other is also an important aspect of WL, creating a dynamic tension between the "translatables" and "untranslatables" of intercultural communication, a dynamic that is of course not stable, but constantly ebbs and flows. Readers familiar with the history of Germanistik in Germany may be wondering why I have paid so much attention to an essay by Dr. Petersen, who just a few years later became a Mitläufer of National Socialism in publishing one of the more notorious works of völkisch literary scholarship, Die Sehnsucht nach dem Dritten Reich in deutscher Sage und Dichtung (The Desire for a Third Reich in German Saga and Literature) in 1934. One reason is that I wish in this introduction to give a fuller account of thinking about WL in Germany, going beyond the perhaps 80 percent of articles that concern themselves only with Goethe, or at most with Auerbach as well. The second reason, however, is that Petersen's retreat from comparative and WL between 1927 and 1934 corresponds at its beginning to the relatively open, cosmopolitan orientation of the years when the Weimar Republic seemed like it might actually succeed, with translations and WL making an important contribution to the literary corpus, and at its other end to the years of Nazi rule during which German authors were forbidden from accepting international literary prizes, among other mechanisms-including the exile and statelessness visited upon so many prominent authors-for reshaping Germans' relation to WL as purely exogamous.

Figure 2 suggests the point made by Abram de Swaan, who argues that the political centrality of a language should be determined less by the number of native speakers,

16 Moretti, "Evolution, World-Systems, Weltliteratur" 115.

17 Manfred Koch, "Deutsche Welterleuchtung oder globaler Ideenhandel?" 42. 
and more by the number of multilingual speakers it has-the overlaps between the circles. Swann uses a number of metaphors in order to map the relations between languages of the world, including Venn diagrams and the nested relations of heavenly bodies. Just as the moon revolves around the earth that revolves around the sun that traverses the galaxy, so too one proceeds from dialects to "national" languages to supranational languages as ever-widening constellations of cultural communication:

There are roughly a dozen supranational languages. Sometimes, while central in their part of the system, they dominate by dint of the number of their native speakers, the sheer weight of their plurality: Chinese, German, and Japanese function mainly as native languages on a very large and contiguous territory, but at the same time as second languages they link a number of surrounding speech groups into a communication system. ${ }^{18}$

Migration patterns and technological development have complicated our originary understanding of what "primary" might mean. Austria, Germany, and the German language's particular position vis à vis other languages contributes to German's relative centrality in the development of conceptions of WL. To give one example, Jürgen Joachimsthaler has studied the "text-margins" (Text-Ränder) of Germany's interactions with Slavic cultures in the east, and especially with Serbs, Lithuanians, Poles, and so forth. The question is one of how literature written in German can convey a multicultural reality. For example, Joachimsthaler describes the role of "the Polish" in Gustav Freytag's Soll und Haben: "Matters force their way into the text that should remain outside its German world according to the centrally German point-ofview - for which reason they are placed on the Polish side and there represent exactly what should not trespass onto the German side. The text thus imagines within itself its own exteriority [sein eigenes Ausserhalb]." ${ }^{19}$ Contributor Simona Moti carries out an analogous analysis on the work "Reitergeschichte" (Tale of the Cavalry) by the Austrian writer Hugo von Hofmannsthal, prefacing her reading analysis with a review of Hofmannsthal's ambiguous writings on Austrian multiculturalism and with his correspondence with leading members of its Slavic population that reveal how his dreamlike tale imagines the Slavic exteriority of empire.

This reflective process that appropriates the eyes of the other begins with the earliest piece of writing about Germany, the Germania of the Roman writer Tacitus. Tacitus' goal in composing this text was probably not ethnographic precision, but the admonishment of his own compatriots. The result was the literary composition of an anti-Roman located in the supposedly scrupulous, monogamous, democratic, and warlike Germans. The text began to be accepted as a foundational, transtemporal fixing of German qualities once it had served the French philosophe Montesquieu, who linked the woodland environment in which the Germans lived to their republican virtues. Christopher Krebs has shown how the text's deployment as a foundational

18 Abram de Swaan, “The Emergent World Language System: An Introduction," International Political Science Review, 14.3 (July 1993), 220.

19 Jürgen Joachimsthaler, Text-Ränder: Die kulterelle Vielfalt in Mitteleuropa als Darstellungsproblem deutscher Literatur, 2 vols. (Heidelberg: Universitätsverlag Winter, 2011), 1:187. 
document for German nationalism obscured the ongoing inquiries of a small minority into the troubling questions of what the text's original purpose was, and how accurate it could have been-leaving aside the question of why modern Germans would prefer transtemporal identification with a vanished people to self-fashioning in the present. ${ }^{20}$ But this transtemporal aliveness is precisely what makes the Germania a work of literature. Bottom line: for 200 years the Germans have used a text written by a Roman and translated from Latin to help define who they are. WL has become German literature.

\section{World literature as German literature}

Wenn diese Literatur ihrem Ursprung nach nicht bloss eine deutsch-nationale ist, so bezeichnet ihr Auftreten auch nicht bloss eine Epoche in der Geschichte der deutschen Literatur, sie hat eine welthistorische Bedeutung: jene Weltliteratur selbst, auf welcher sie beruht, bekommt durch sie eine neue Richtung.

[If this literature is not simply a German national one according to its origins, so too its appearance designates not simply another epoch in the history of German literature, but has a world-historical meaning: the world literature on which [modern German literature] rests receives a new direction through it.]

Theodor Wilhelm Danzel, "Ueber die Behandlung der geschichte der neueren deutschen Literatur" $1847^{21}$

These words of Theodor Wilhelm Danzel are remarkable, first of all for the near-messianic tone with which they treat WL as an epiphenomenon of German exceptionalism. They bear comparison with Goethe's career, in that like the latter's own literary production they speak simultaneously to the emergence of the fields of both Germanistik and WL, in dialectical relationship with one another. Goethe first used the term WL in an oracular, prophetic manner that allowed for a continuous engagement with it as a topic and for its continued influence in German letters, at the end of a phenomenal career that had helped bring German literature out from under the shadows of its former models in France and England, an apprenticeship that Danzel refers to in his address. Of course, the simultaneity of the emergence of these two attitudes towards literature, along with the explicitly ideological calls for a German literary tradition as part of nation-building on the part of Jacob Grimm, J. G. Fichte, and Ernst Moritz Arndt, contributed to making them rivals with each other. Goethe was urged more than once to transadapt the Nibelungenlied in order to provide modern German literature with a foundational text, on the analogy of Athenian tragedy's relationship to Homer. ${ }^{22}$ Goethe resisted such calls

${ }^{20}$ Christopher B. Krebs, A Most Dangerous Book: Tacitus's Germania from the Roman Empire to the Third Reich (New York: Norton, 2011).

21 Theodor Wilhelm Danzel, "Über die Behandlung der geschichte der neueren deutschen Literatur," in Gesammelte Aufsätze, ed. Otto Jahn (Leipzig: Dyck, 1855), 201.

22 See Patrick Fortmann, "Romanticism's Old German as Stepping-Stone to Goethe's World Literature," Goethe Yearbook 20 (2013), 247-63. 
in favor of the cosmopolitan approach, embodied most succinctly in his famous pronouncement to Eckermann, "Nationalliteratur will jetzt nicht viel sagen, die Epoche der Weltliteratur is an der Zeit, und jeder muss jetzt dazu wirken, diese Epoche zu beschleunigen" [National literature has not much meaning nowadays: the epoch of world literature is at hand, and each of us must work to hasten its coming (Strich Goethe and World Literature 349)]. ${ }^{23}$ Why not posit the origins of German literature as multiple, and as including Greek tragedy, Tacitus, Horace, the Bible, Italian novelle, and so forth-so Goethe seemed to argue implicitly? But the owl of Minerva only spreads its wings and flies at night. It fell to Danzel, as Hans Mayer so aptly points out, to bring the question of the relationship between German literature and world literature into greater focus and to insist that the two must be examined simultaneously in their essential interconnections. Danzel spoke two decades after Goethe's pronouncement, and with G. G. Gervinus delivering in the intervening years the first comprehensive, "standard" history of German literature, a Geschichte der poetischen National-Literatur (History of Poetic National Literature), published in five volumes between 1835 and $1842 .{ }^{24}$ Gervinus skipped over WL in order to express the uniqueness of German literature as its expression of a universal idea of humanity that the Germans shared uniquely with the Greeks. A bit later, at the University of Göttingen, Karl Goedeke worked on his "Umriss zur Geschichte der deutschen Dichtung" simultaneously with one of the first attempts at Stoffgeschichte in WL (the latter project unfortunately, but perhaps symptomatically, not coming to fruition).$^{25}$ Furthermore, historical events drove both attempts: the same Napoleonic wars that had furthered Germans' love of the fatherland as a reaction to occupation (and that had consolidated some of the hitherto scattered and independent German states) also brought about the increased commercial and political relations between nations that inspired Goethe's idea of WL. (Indeed, Shaden Tageldin has argued that Napoleonic conquest within and beyond Europe bore a direct relation to the invention of littérature comparée [comparative literature], "a term that first appears in French in 1816 because France had a stake, in that (post)imperial historical moment,in styling itself a world-origin." $)^{26}$

A negative example of recognition of German literature's relationship to WL is found in August Koberstein's Grundriss der Geschichte der deutschen Nationalliteratur, begun as an outline in 1827, and expanded into a full history in five volumes 1872-84. In his preface, Koberstein carefully distinguished between literature by Germans, and German national literature: "The literature of the Germans in general comprises the whole of creative products [Geistesprodukte] laid down by this people in speech and in writing, without regard to content or form of these products. German national literature is a part of that whole. It comprises, strictu senso, only those written works

23 Johann Peter Eckermann, Gespräche mit Goethe in den letzten Jahren seines Lebens (Munich: Beck, 1984), 198; Strich, Goethe and World Literature 349.

${ }^{24}$ Hans Mayer, "Deutsche Literatur und Weltliteratur," in Deutsche Literatur und Weltliteratur, 169-76.

25 Cf. Julius Petersen, 38-9.

${ }^{26}$ Shaden M. Tageldin, “One Comparative Literature?” Comparative Literature Studies 47.4 (2010), 423. 
that have been produced in an artistic manner, exhibiting a German character [deutsches Gepräge] in their form as well as in their content." ${ }^{27}$ Koberstein acknowledges that other literatures have influenced the German, "and in so doing perhaps have undermined its national character [Volksthümlichkeit] and threatened it with complete destruction." ${ }^{28}$ It would seem that Josef Nadler's infamous literary history, Literaturgeschichte der deutschen Stämme und Landschaften (1912-1928; Literary History of the German Tribes and Landscapes), created on the theory that each region of the German-speaking countries (or alternately, each German Stamm) had produced a literature that reflected its landscape or the character of its people, would represent the epitome of this kind of approach, but in fact the division of German literature into a myriad of tribal literatures created an unusual dynamic that caused Nadler to formulate his own approach on the analogy with that of WL:

The geographical (or better, tribal-historical) factor [landschaftliche (besser stammesgeschichtliche) Moment] is to be compared in all its aspects to the national perspective, through which we observe world literature. [...] But just as we prefer to consider a specific ethnographic unit, differentiated through political and geographical factors, as the true vector [Trägerin] of literature, and to use comparative literary history in order to do justice to the overall human connections, so too with our national literature. The tribes [Stämme] bear the same relation to German national literature as nations [Völker] bear to world literature..$^{29}$

One might think that world literature succeeds national literature, just as globalization ${ }_{\mathrm{Ca}}$ seems to be a stage that depends upon the infrastructures provided by national frameworks. Indeed, we will soon see Marx's model in which WL emerges in just such a fashion. Yet the above examples have shown that the two concepts are created almost in tandem. Pascale Casanova points out two important things about national literature formations. One states that national literature is not synonymous with national character. The second identifies one source of literature's autonomy: national literatures are formed not in isolation, but in relation to other literatures. Generally, there is a literature that is seen as more advanced and to be imitated, as in the case of Chinese for early Japanese literature, Renaissance Italian for French literature, or French for modern German literature. This tendency of national literatures to shape themselves within a network of WL comparisons, even if these are purely oppositional, can also be counted as an aspect of Goethe's cosmopolitan model.

Grundriss der

27 August Koberstein, Geschichte der deutschen Nationalliteratur, 5 vols., $6^{\text {th }}$ edn. (Leipzig: F. C. W. Vogel, 1884), 1:1.

28 Koberstein, 1:2.

29 Letter to August Sauer, 17 December 1910; cited in Irene Ranzmeier, Stamm und Landschaft (Berlin: De Gruyter, 2008), 103. 


\section{The world literature connection}

Goethe's development of the idea of Weltliteratur has been treated many times, by Fritz Strich, John Pizer, and others. Scholars tend to compress the long, detailed, and often contentious institutional history of WL in Germany and have Goethe speak to their age in particular. David Barry, for example, in a 2001 article on Goethe's WL, cites the "somewhat melancholy judgment" of a 1999 German newspaper on the idea's fate, which notes that the euro was born in the same city as the inventor of the term Wel (1t) atur. ${ }^{30}$ Fritz Strich and Hans Joachim Schrimpf are two scholars who see the restoratron of the concept of WL as an overcoming of the pull of nationalism.

One scholar who worked to carry out Goethe's exhortations to WL was Karl Marx. Like Goethe, Marx, after all, was attuned to the close connections between economic and intellectual commerce. His early, unfinished novel, Scorpion und Felix, alludes to Sterne, Heine, Ovid, and the Bible (see Prawer 15-16). The idea of WL coordinated very well with the Hegelian philosophical idea of the connectedness of cultural events worldwide, as we have seen above, but also went hand in hand with the commercial unity of the world being brought about by capitalism. Yet neither Marx nor Engels produced an extended piece devoted to the topic of literature, let alone to WL. Like Goethe, they merely referred to it and located it within the world-system of bourgeois capital, as in this passage of The Communist Manifesto:

The bourgeoisie has through its exploitation of the world-market given a cosmopolitan character to production and consumption in every country. [...] In place of the old local and national seclusion and self-sufficiency, we have intercourse in every direction, universal inter-dependence of nations. And as in material, so also in intellectual production. The intellectual creations of individual nations become common property. National one-sidedness and narrow-mindedness become more and more impossible, and from the numerous national and local literatures, there arises a world literature. ${ }^{31}$

Marx, then, is one example of what Peter Gossens has called the turning from an attempt at conceptualizing WL, to one of constituting it as an object of literary study in the writing of transnational literary histories and the creation of anthologies. ${ }^{32}$ Indeed, Johannes Scherr published the first edition of his Bildersaal der Weltliteratur in the revolutionary year of 1848 . It would go through a number of re-editions, and be joined by other anthologies by Adolf Schwarz, Hermann Hettner, and Adolf Stern. In his preface, Scherr took up the Danzel's theme of Germany's WL exceptionalism, itself and inflation of the "ehrenvolle Rolle" (honorable part) Goethe had parsed out for Germans: "Ein Buch wie das vorliegende ist nur in Deutschland möglich" [A book

30 David Barry, "Faustian Pursuits: The Political-Cultural Dimension of Goethe's Weltliteratur and the Tragedy of Translation," German Quarterly 74.2 (Spring 2001), 164.

${ }^{31}$ Karl Marx and Friedrich Engels, Manifesto of the Communist Party, in The Marx-Engels Reader, ed. Robert C. Tucker (New York: Norton, 1978), 476-77.

32 Peter Gossens, "Weltliteratur: ein schillernder Begriff," IDE 1 (2010), 17. 
such as you hold in your hands is only possible in Germany] (Bildersaal VI). ${ }^{33}$ Scherr's following comment on the universality of the German Geist (spirit/intellect) that makes such an anthology possible will be echoed in the early-twentieth century by Rudolf Eucken in the context of the preservation of idealism in the face of materialistic theories of existence.

A century later, in East Germany, Marx's model of WL went hand in hand with the self-proclaimed internationalism of Communism, as noted above. In contrast, as the editors of a special issue of the Austrian journal IDE report, attempts at introducing WL into the Austrian school curriculum after 1945 were not lasting, despite the fact that the textbook for the Sekundarstufe II was called Lesebuch der Weltliteratur (World Literature Reader). In particular, the granting of full sovereignty to Austria in 1955 made these first efforts disappear, giving the impression that the focus on world literature had been a sign of lack of national sovereignty. In the current curricula for both Gymnasien and vocational schools, there is a requirement that students acquire "einen Überblick über die deutschsprachige Literatur im Kontext der Weltliteratur" [an overview of German-language literature in the context of WL]. A 1995 reader, appropriately called Brücken, was the only actual collection of texts of world literature intended for the Sekundarstufe, many of them given both in original languages and German translations, but it has since been removed from the list. A literary textbook called Zugänge remains for Sekundarstufe II.

The nine essays that follow have been grouped into three categories, each with a bilingual title that hints at the (un)translatability of the concept involved: Goethe's Weltliteratur/World Literature; Ausstrahlungen/Emanations; and Schnittmengen/ Intersections. The two essays of the first grouping, by Chunjie Zhang and Daniel Purdy, have been described above. The Goethean concept of WL has shown an ability to take on a life of its own, and toompenect transtemporally with the concerns of whatever historical moment feels ealled on to invoke it. These two essays perform an important function in reminding us, however, of the fact that Goethe's pronouncements on WL were embedded in his acts of reading works of WL, from the Sanskrit drama Shakuntala to the two Chinese novels discussed by Purdy and Zhang, as well as in his adding to the corpus of WL through hybrid texts such as the West-östlicher Divan, the "Chinesisch-deutschen Jahres- und Tageszeiten," and even, as Zhang argues, the earlier novel Wahlverwandschaften (Elective Affinities).

"Emanations" refers to the focus on individual writers and on the pathways by which their work enters the force-field of WL. In the vexed dealings of Hugo von Hofmannsthal with representatives of some of the Slavic cultures of Austria, Simona Moti gives us a prime example of the impurity of national literature, given its construction on the basis of difference from what the ethnic other is capable of producing. Moti's essay shows how Hofmannsthal's preoccupation with Austria's ethnic others returns symbolically in the violence of his "Tale of the Cavalry." Kathleen

${ }^{33}$ Goethe's phrase occurs not in the conversation with Eckermann, but in an article on Duval's drama Le Tasse published in Über und Altertum, vol. 6, part 1 (1827). Cf. Strich, Goethe and World Literature, 349. 
Komar takes a different approach to WL-that of the hypercanon-in exploring the paradoxical phenomenon of poets like Rainer Maria Rilke, whose work is deeply embedded in the specificities of German language, and yet who has been translated and appreciated in many different languages worldwide, entering the canon of "world poets" alongside Hafiz, Rumi, Ghalib, and Bashō. Conversely, however, as is well known, the triumph of fascism and of officially sanctioned anti-Semitism in the 1930s marks a particularly poignant historical moment when "unerwünschte" (unwelcome) authors became, in their physical persons, vectors for the diffusion of German literature into other languages and cultures. For Bertolt Brecht, as a playwright influenced by Asian and other non-European performance styles, exile represented yet another, culminating stage in his attempt at smashing Western drama's Aristotelian mold. Even Brecht's return to the (now East) German Fatherland ended up being more of a triangulated, transnational affair than a triumphant return home, as Martina Kolb details in her essay. The career Germanist and novelist W. G. Sebald (1944-2001) could be termed a "second-generation" exile; he was forced to leave Germany not by political decree, but by the cultural forces of amnesia, psychic foreclosure, and the inability to mourn in his homeland that returned to haunt his fiction as narratives of militant melancholy-a melancholy, as David Kim'sienalysis shows, that reveals in ghostly fashion the globalized traumatic events that are at its root.

The last grouping of essays, Intersections, starts to fill in the ring model of Figure 2 with detailed information on the systematic programming of WL interactions. For more than a century, the Nobel Prize for Literary Achievement has been a highly regulated and thus highly visible mechanism for test-runs at WL status for national authors. (It has been somewhat less widely known as an intersection between Swedish and other national literatures.) My own chapter provides a case study of two failed runs at this status by German authors in the first decades of the twentieth century-failure in this case acting like an X-ray that reveals the inner workings of the mechanisms of fame and impact that remain hidden when the prize seems to have been inevitable given the literary value of the work. Paul Nissler's essay takes a different approach to the intersections between German and Latin American literatures, attempting to populate them with bibliographic and in some cases biographic information. The cast of characters in Nissler's history is immense. His essay begins and ends with Alexander von Humboldt as an emissary, a bridge, and finally an image between cultures and languages. He then complements Humboldt's monumentality with a plethora of less well-known efforts that depended upon German travel to and residence in Latin America, and of Latin Americans finding refuge in Germany. WL is created out of this trading of place and the concomitant triangulation of viewpoints, as Latin American realities find expression in German. It is fitting that Elke Sturm-Trigonakis's essay closes the volume, because her concept of "New WL" shows how unstable the elliptical model of WL becomes when the two foci of the ellipsis exist outside of any "national" literature. As she points out, in the Germany of the twenty-first century "the term 'national literature' is being questioned more than ever, especially because of the manifest presence of a transnational, linguistically and culturally hybrid literature which as 'interkulturelle' or 'Migrationsliteratur' 
leads a precarious existence within German national philology" (180). Despite the apparent newness of the "New WL," it reminds us of some old topoi, for example of the metropolis as a node within a "dehierachized, rhizomatic world-system, where one place can easily be substituted by another" (187). This should remind us of Spengler's observation that WL is "weltstädtische Literatur" (cosmopolitan literature), as well as of Goethe's discussion of WL as a form of intellectual commerce between peoples. Sturm-Trigonakis argues that New WL exists as an independent literary system rather than as an intersection - in other words, texts of New WL relate far more to each other than to any national canons to which they may be assigned. This is a strong argument, and an interesting metric by which to evaluate literary production over the next few decades.

The aim of this introduction has been to hint at the necessity for a dynamic modeling of WL, both in the sense that interactions between literatures are systemic, historically conditioned, and hence subject to change, and that the valorizing of WL has been taken seriously in German intellectual discourse, while also fluctuating through the centuries in its relative claims on the attentions of Germanists. Recent predecessors in the same category of undertaking as here include Clark and Lubrich's Transatlantic Echoes: Alexander von Humboldt and World Literature (2012), and Fuechtner and Rhiel's Imagining Germany Imagining Asia (2013), volumes that join the previous work of Azade Seyhan and Leslie Adelson, among many others, in attempting to formulate critical paradigms for coming to grips with literary texts that find or have a life outside the nation. ${ }^{34}$ We hope there will be many successors to this volume of essays, this our point of departure into WL.

${ }^{34}$ See e.g., Azade Seyhan, Writing Outside the Nation (Princeton: Princeton UP, 2001); Leslie Adelson, ed. The Cultural After-Life of East Germany: New Transnational Perspectives, Helen \& Harry Gray Humanities Program Series 13 (Washington, D.C.: American Institute for Contemporary German Studies, 2002), and Leslie Adelson, The Turkish Turn in Contemporary German Literature: Toward a New Critical Grammar of Migration (New York: Palgrave Macmillan, 2005). For yet another perspective,

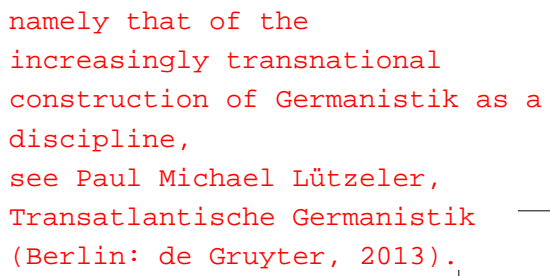

